Гордана Ђоковић

Универзитет у Београду

Филолошки факултет
УДК 027.022:004

ДОИ https://doi.org/10.18485/

melissa.2016.15.2.ch8

\title{
УЛОГА НАРОДНИХ БИБЛИОТЕКА У РАЗВИЈАҢУ ДИГИТАЛНЕ ПИСМЕНОСТИ
}

\section{Сажетак}

Библиотеке су одувек пратиле промене у друштву, а преносећи знање и информације и утицале на те промене и биле њихов носилац. У данашњој електронској ери оне, прилагођавањем и реорганизацијом, постају информациони центри, па поред васпитно-образовне улоге добијају и нови концепт. Оне сада морају одиграти кључну улогу у дигиталном описмењавању и прихватању нових технологија задржавајући при том своје раније образовне вредности.

Будући да народне библиотеке представљају прави репозиторијум знања а уједно и пријатан простор за учење и социјализацију, оне представљају и идеално место за ширење и развијање дигиталне писмености међу својим корисницима. У раду се указује и на потребу да народне библиотеке у будућности преузму улогу центра за деинституционализовано и неформално образовање и да у својим просторијама организујуобукуали ипружајуподршкуграђанимау коришћењунових технологија. На тај начин, оне могу помоћи у побољшању дигиталне писмености као и у спречавају неуједначености у коришћењу дигиталних технологија.

Кључне речи: народне библиотеке, дигитална писменост, информациона писменост, пројекти.

Данашње време, време „експлозије“ информација, које почиње у другој половини 20. века, је врло специфично. Појава интернета и нових технологија имала је утицај на библиотеке попут утицаја који је извршила појава штампе у 15. веку. Библиотекарство се, као и много пута раније, нашло пред великим испитом. Постојало је много теорија како ће будућност библиотека изгледати од којих је најпесимистичнија свакако она да „револуција коју је донео интернет, уз могућност неограниченог доступа до информација, учиниће 
непотребним даље постојање јавних народних библиотека.“1 Ипак, ако имамо у виду да је, као што тврди Мајкл Горман, председник Америчког библиотечког удружења, „вештина читања и писања исто тако битна за успешно коришћење рачунара колико је битна и за све друге облике комуникације“2, најреалнија је теорија „активног преображаја традиционалних служби и услуга јавних библиотека и њихов развој као културних и информационих центара локалне заједнице." ${ }^{3}$

Образовање стечено редовним школовањем није довољно у данашње време. Брзе промене у свим сферама живота захтевају непрестално учење, односно континуирано образовање сваког човека па се образовање данас проширује на све животне доби.

Народне библиотеке су увек помагале формално образовање, али су такође својим фондовима задовољавале потребе локалног становништва за информацијама и након завршетка редовног школовања. Оне су се увек, кроз историју, трудиле да одговоре потребама времена, како својим разноврсним модерним фондовима, тако и оснивањем различитих помоћних служби, курсева, предавања као вида помоћи у неформалном, неинституционализованом учењу.

Унапређивањем својих услуга, народне библиотеке могу да се суоче са изазовима дигиталне неједнакости и да спрече њено ширење на процесе који се односе на образовање. Развојем е-учења у народним библиотекама повећава се дигитална писменост становништва а самим тим повећавају се и могућности за запослење али и разлике између дигитално писменог и дигитално неписменог становништва при чему ови други губе многе прилике.

Е-учење је и најважнији део концепта доживотног учења због могућности велике друштвене укључености становништва. Е-учење омогућава приступ образовању свима, а нарочито онима којима је приступ отежан због социјалних, економских, географских или других разлога.

1 Јавне библиотеке и јавно знање / Жељко Вучковић. - Нови Сад : Библиотека Матице српске: Футура публикације, 2003. - Стр. 7.

2 Youth Services and Public Libraries / Susan E. Higgins. - Oxford : Chandos Publishing, 2007. - XIII, 153 str. : ilustr. ; 23 cm. - (Chandos Information Professional Series). - Str. 22.

3 Јавне библиотеке и јавно знање / Жељко Вучковић. - Нови Сад : Библиотека Матице српске: Футура публикације, 2003. - Стр. 7 
Тако модернизоване народне библиотеке постају центри културе једне заједнице и свима пружају по нешто: незапосленима податке о новим могућностима запослења, младима места за састанке и дружења, деци нуде напредне и разноврсне програме који се заснивају на вештинама које се уче у школи, пензионерима су места где читају новине које не могу да приуште, а особама са посебним потребама установе у којима их сви уважавају и које су прилагођене њиховим потребама.

Народне библиотеке имају улогу да подстичу учење, било формалне, било неформалне природе. Оне као установе нуде широк избор различитих медија као и стручну помоћ у тражењу информација. Такође, оне оспособљавају појединце да самостално трагају за информацијама и тако дођу до знања. у библиотекама у којима се спроводи концепт целоживотног учења, могуће је пронаћи публикације за све узрасте, и за разоноду али и за формално и неформално образовање. Поред богатих библиотечких фондова, овакве библиотеке богате су и разноврсним програмима које организују у циљу промовисања читања и ширења писмености, како оне елементарне тако и оне рачунарске или информационе.

Библиотеке су одувек пратиле промене у друштву, а преносећи знање и информације и утицале на те промене и биле њихов носилац. У данашњој електронској ери оне, прилагођавањем и реорганизацијом, постају информациони центри, па поред васпитно-образовне улоге добијају и нови концепт. Оне сада морају одиграти кључну улогу у дигиталном описмењавању и прихватању нових технологија задржавајући притом своје раније образовне вредности.

Као одговор на „експлозију“ информација настао је концепт информационе писмености. „Информациона писменост је способност да се лоцира, евалуира и ефектно користи тражена информација."

Информационо описмењавање становништва се углавном изводи у земљама које су развијене у технолошком, економском

4 Улога библиотека устварању информационо писменог појединца / Милица Матијевић // Библиотеке и тинејџери: зборник радова / ур.Елизабета Георгиев и Надица Костић. - Пирот : Народна библиотека Пирот ; Димитровград : Народна библиотека „Детко Петров", 2012. - Стр. 154. 
и друштвеном погледу и углавном се везује за образовање и библиотекарство, а обухвата целоживотно учење, право на приступ информацијама, друштво знања, економију утемељену на знању итд.

Доживотно учење као универзална вредност свуда у свету, представљауједноимисијусвакенароднебиблиотеке.Информационо доба у коме данас живимо, тежи да искористи све предности информационих наука и технологија и да створи информационо друштво у коме ће све бити доступно путем интернета и у коме ће и становништво бити информационо писмено. Зато је приоритет већине влада у свету, укључивање становништва у информатичко доба и ширење информационе писмености.

Народне библиотеке могу одиграти важну улогу у информационом описмењавању будући да оне представљају прави репозиторијум знања, складиште са информацијама различитих формата, пријатан простор за учење, место за социјализацију знања, место у којем је омогућен приступ рачунарима и информацијама на интернету.

У данашње време када нас од огромне количине информација дели само један клик мишем, информациона писменост обухвата и могућност да се у том мору информација пронађе она права. Проналажење и приступ информацијама мањи је проблем од вредновања и одабира истих.

Информациона писменост је услов за целоживотно учење које је уграђено у стратегије и реформе образовања. Целоживотно учење није могуће без информационе писмености, а информациона писменост је опет неопходна свима за успешно целоживотно учење, проналажење посла и свакодневну комуникацију. Информационе способности су важне за целоживотно учење и потребне су целога живота. Библиотекари би требали да одиграју важну улогу у информационом описмењавању, осмишљавањем разних програма за унапређење информационе писмености локалног становништва и развијања вештина и знања потребних за целоживотно учење.

Вука Јеремић сматра да су „елементарни услови за проналажење кредибилних извора информација на мрежи критичка евалуација и селекција, а да су ту у предности генерације са традици- 
оналним образовањем које могу бити објективније у односу на „Гугл генерације". Она каже да су брижљив селективни приступ приликом грађења и развоја дигиталних колекција уз развијање корисничких навика које подразумевају информациону писменост, али и етичан и колегијалан приступ новим информационим изворима прави одговор на питање како искористити предности нових технологија. ${ }^{5}$ Слично мишљење има и Сузан Хигинс, америчка библиотекарка, која каже да се улога библиотекара у јавним библиотекама „све више посматра као улога посредника између деце, њихове браће и сестара, родитеља или старатеља и библиотечких извора - то је традиционална улога у модерном добу.“6

Са наглим променама у друштву, и знања брзо застаревају тако да и ,професионалац мора без престанка да учи. “" Библиотекари данас морају да се контиунирано образују због личног усавршавања и да би могли „да обезбеде добру и брзу услугу“8 каква се данас и захтева. Континуирано образовање може бити лично и професионално. Прво са циљем да се унапреде лична интересовања, а друго са циљем усавршавања методе и технике рада не би ли се постигли бољи резултати. Образовна активност почиње проценом потреба полазника, затим се израђују план, програм и стратегија учења, а по завршетку учења следи евалуација која је последњи део тог процеса и први део следећег процеса образовања јер се подаци користе за процену потреба наредног процеса. То чини евалуацију основом на којој почива квалитет образовног процеса.

Рад на информационом описмењавању круцијалан је у 21. веку, у којем је образовање перманентан процес. Посебно је важно посветити пажњу у раду са младима који буквално одрастају на новим технологијама. Такав начин одрастања их доводи у ситуацију да

5 Селекцијом до квалитета, а етиком до културе коришћења електронских извора информација у академским библиотекама / Вука Јеремић, // Култура бр.1 (2010): Стр. 216.

$6 \quad$ Youth Services and Public Libraries / Susan E. Higgins. - Oxford : Chandos Publishing, 2007. - XIII, 153 str. : ilustr. ; 23 cm. - (Chandos Information Professional Series). - Str. 27.

7 Континуирано образовање високошколских библиотекара / Гордана Вилотић и Славица Несторовић-Петровски // Инфотека. - Год.7, св.1/2 (2006). - Стр. 34 Исто. 
стичу лажну претпоставку да једноставним отварањем прве странице коју избаци Гугл претраживач долазе до адекватних података. У океану информација свакодневно до нас стиже много оних које су нефилтриране. Информационо писмена особа мора да има систематичност у претраживању, да уме да развије план претраживања који ће у току самог претраживања смислено прилагођавати. Потребно је знати користити референсну литературу, обратити се библиотекару за помоћ, правилно цитирати, издвојити одговарајуће цитате, користити чланке у часопису, on-line каталоге и друге базе података, знати да се правилно претраживање Гугла разликује од проналажења информација у књизи, али и од претраживања електронсог каталога... Дакле, потребно је поседовати много вештина и константно учити нове. Такође, важно је да и библиотекари схвате да овакав концепт целоживотног учења утиче и на њих, па и они сами добијају нове улоге. Они су такође принуђени да посећују семинаре, стручна предавања и уче до краја живота јер да би помогли некоме у стицању знања, морају и сами да поседују одређено знање. Нове технике претраживање се стално појављују, а интернет стално трпи промене, па је важно бити у току. Циљ оваквог начина лоцирања, евалуирања и коришћења информација јесте особа која ће на основу обрађених података и њихове анализе синтезом формирати сопствено мишљење и на тај начин стварати нова знања. Врло је јасно како библиотеке, посебно народне, и библиотекари који раде у њима могу и морају одиграти кључну улогу у информационом описмењавању друштва.

Народне библиотеке се данас налазе на раскрсници која нуди различите могућности за њихов даљи развој. Убрзани развој информационих технологија, принудио је и народне библиотеке да се мењају страховитом брзином како би ишле у корак са временом. Оне су данас разапете између очувања традиционалне, просветитељске улоге и потреба и захтева новог информатичког доба. „Ми морамо пратити друштвене промене, али то не значи да смемо срушити вредне и корисне институције какве су народне библиотеке. Не смемо се повијати пред сваким таласом промена. Само снажне структуре могу се одупрети хладним ветровима. Нећемо се, без добрих разлога, одрећи начела и вредности на којима су створене народне 
библиотеке. То су заједничке вредности нашег друштва и библиотекарске професије, које ће обликовати и наш будући свет, више него све технологије, економске теорије и помодне идеоалогије. Одлука је на библиотекарима и ми можемо начинити прави избор“9.

Видно је приметно да се традиционалне услуге, као што је позајмица књига драстично смањују, и због те чињенице народне библиотеке се морају мењати још брже и прилагођавати новонасталој ситуацији. Народне библиотеке би требале да искористе нове медије, информационе и комуникационе технологије како би квалитетније, успешније и брже обављале своје традиционалне, образовне, културне, информационе и рекреационе функције.

Ипак, народне библиотеке морају задржати своју главну улогу у осигуравању писменог информационог друштва. Оне, на јефтин начин осигуравају приступ штампаним текстовима, али у исто време омогућавају својим корисницима и јефтин приступ интернету и online садржајима.

Многа деца данас у Свету одрастају уз компјутер и услуге интернета, али и даље је велики број деце а нарочито одраслих који немају приступ интернету и не поседују вештине помоћу којих би ове услуге користили. Управо ту је и шанса за народне библиотеке, које би требале да се усмере на потребе ових група људи.

Народне библиотеке би требале да нуде перманентно усавршавање за све своје кориснике, нудећи пријатно и стимулативно окружење за децу и њихове школске активности али и разоноду. Народне библиотеке би требале да преузму улогу центра за деинституционализовано и неформално образовање и да у својим просторијама нуде обуку и подршку грађанима у свим етапама живота, коришћењем нових технологија и могућности електронског учења.

Оне помажу и у побољшању дигиталне писмености и спречавају неуједначеност у коришћењу дигиталних технологија. У данашњем глобализованом свету, народне библиотеке нарочито помажу да се код људи задржи осећај припадности локалном окружењу и поро-

9 The public library as public knowledge / Bob Usherwood. - London : Library Association, 1989. - Str. 2 
дици. Подржавају етничке, културне, језичке и верске различитости, културни идентитет и друштвену интеграцију.

\section{Литература}

Јавне библиотеке и јавно знање / Жељко Вучковић. - Нови Сад : Библиотека Матице српске : Футура публикације, 2003 (Нови Сад : Футура публикације). - 180 стр. ; $23 \mathrm{~cm}$

Youth Services and Public Libraries / Susan E. Higgins. - Oxford : Chandos Publishing, 2007. - XIII, 153 str. : ilustr. ; $23 \mathrm{~cm}$. - (Chandos Information Professional Series)

ISBN 1-84334-156-5

Улога библиотека у стварању информационо писменог појединца / Милица Матијевић // Библиотеке и тинејџери: зборник радова /ур.Елизабета Георгиев и Надица Костић. - Пирот : Народна библиотека Пирот ; Димитровград : Народна библиотека „Детко Петров“, 2012. - Стр. 154.

Информационо описмењавање у фокусу етике / Александра Вранеш, Љиљана Марковић // Информациона писменост и доживотно учење / уредници Александра Вранеш, Љиљана Марковић, Гвен Александер. - Београд : Филолошки факултет Универзитета : Библиотекарско друштво Србије ; [Вичита] : Емпориа универзитет, 2008. - ISBN 978-86-86419-50-7. - Стр. 113-116.

Јавне библиотеке између стандарда и слободе информисања / Александра Вранеш // Библиотекар. - ISSN 0006-1816. - Год. 50, св. 1/2 (2008), стр. 5-26.

Селекцијом до квалитета, а етиком до културе коришћења електронских извора информација у академским библиотекама / Вука Јеремић, // Култура бр.1 (2010): - Стр. 216.

Јавне библиотеке, јавне информације: дигитално описмењавање и грађанин / Роб Дејвис и Јоанис Трохопулос ; превела са енглеског Биљана Ракочевић. // Гласник народне библиотеке Србије. - ISSN 1450-8915. - Год. 4, бр. 1 (2002), стр. 213.

http://www.nb.rs/view_file.php?file_id=611

Континуирано образовање високошколских библиотекара / Гордана Вилотић и Славица Несторовић-Петровски // Инфотека. - Год.7, св.1/2 (2006). - Стр. 34

The public library as public knowledge / Bob Usherwood. - London : Library Association, 1989. - Str. 2

Будућност јавних библиотека и професионална одговорност библиотекара / Жељко Вучковић // Библиотекар. - ISSN 0006-1816. - Год. 50, св. 1/2 (2008), стр. 49-55.

Lifelong learning in public libraries : principles, programs, and people / Donna L. Gilton. Maryland : The Scarecrow Press, 2012.

ISBN 978-0-81088-356-7

Иновације у библиотекама за друштво знања / Кирстен Дротнер ; превела Мирослава Дукић // Годишњак Библиотеке Матице српске. - ISSN 0351-3580. - (2005 [шт. 2006]), стр. 191-196. 
THE INTERNET, Networking and the Public Library / edited by Sarah Ormes ...[et al.]. London [etc.] : Library Association Publishing [etc.], 1997. - XIII, 162 str. ; 24 cm ISBN 1-85604-202-2

\title{
Gordana Đoković \\ University of Belgrade \\ Faculty of Philology
}

\section{THE ROLE OF PUBLIC LIBRARIES IN DEVELOPMENT OF DIGITAL LITERACY}

\begin{abstract}
Summary
Libraries have always accompanied changes in society, and transferring knowledge and information they have impact on these changes and become their holder. In today's electronic age they become information centers, and in addition to educational role purchased a new concept. They must now play a key role in digital literacy and acceptance of new technologies while maintaining their earlier educational value.

Since public libraries are a real repository of knowledge but also a pleasant place for learning and socialization, they represent the ideal location for expanding and developing digital literacy among its users. In this paper we demonstrates the need that public libraries in the future should become the centre for the de-institutional and non-formal education and that they should provide training and support to citizens in the use of new technologies. In this way, they can help improve digital literacy and prevent disparities in the use of digital technologies.
\end{abstract}

Key words: public libraries, digital literacy, information literacy, projects. 